Au final, la publication se veut une bonne introduction pour quiconque s'intéresse à l'histoire ouvrière canadienne. Espérions qu'elle saura susciter l'intérêt des chercheurs pour cette célébration bien particulière.

Marc-André Gagnon

Université de Guelph

\title{
Roberta Buchanan, Anne Hart, and Bryan Green, The Woman Who Mapped Labrador: The Life and Expedition Diary of Mina Hubbard (Montreal: McGill-Queen's University Press, 2005).
}

Mina Benson Hubbard Ellis (1870-1956) was born on a Canadian farm, and spent 10 years teaching school in Ontario before leaving Canada to study nursing in New York. There she met and married American journalist and amateur adventurer Leonidas Hubbard. Following Hubbard's 1903 death in the Labrador wilderness, Mina organized and led a Labrador expedition of her own. With the help of George Elson and in direct competition with Dillon Wallace (both of whom accompanied her husband in 1903), Mina successfully travelled by canoe from North West River to Ungava Bay in the summer of 1905. The personal diary and pioneering map of the George and Naskapi Rivers she produced on that trip are at the heart of this valuable collaboration. Introduced and annotated by Buchanan and Greene, the diary is entirely and carefully reproduced (including original corrections and errors), showing respect for Mina's voice. Hart treats the reader to a well-researched biography of its author, including her life after 1905. Combining primary document, secondary analysis, and biography makes this work interesting for general readers, but also valuable for historians of women's experience, relations between First Nations peoples and those of European decent, and middle-class encounters with "wilderness".

The volume opens with a series of short essays placing the diary in a context of gender, class and race relations, geography and landscape, history and biography. This material could have been strengthened through integration into a single introductory essay exploring connections between various elements and themes. The authors' treatment of the indigenous peoples, settlers, and landscape of Labrador is commendable, demonstrating the degree to which place shaped Mina's life and consciousness. Greene compares Mina's expedition with that of Wallace, contrasting personnel and encounter with the Labrador landscape: Mina's largely Native crew was chosen for "experience in the bush," Wallace preferred middle-class white men of "scientific expertise" (10). While Wallace felt a "sense of menace emanating from the land," Mina, informed by "Native values and sensitivities, rather than white paradigms" (as argued by Greene) wrote with "increasing awareness of beauty and harmony in the wilderness around her" (11). Unfortunately, by suggesting this awareness came from 